disease', a condition due to the presence of chlorine, by soaking in sodium sesquicarbonate solution followed by copious washing will often remove all the chlorine without attacking the patina, whilst in aggravated cases, soaking in eitric acid solution or the use of an electrolytic process may be necessary. Fourteenth century glass from Wells Cathedral was found to be coated with material derived from the combined action of an impalpable powder arising from the limestone floor and sulphuric acid provided by the combustion of gas. Other problems the successful solutions of which were described by Dr. Scott included the corrosion of a silver chalice, the unrolling of a manuscript on fragile leather, and the cleaning of marble busts.

\section{Chemical and Photochemical Reactivity}

ON Dee. 17, 1931, the Chemical Society devoted an ordinary scientific meeting to a discussion on the critical increment of homogeneous reactions. It was immediately apparent that the material then presented and the observations then offered should be put on permanent record in an accessible form, and this has since been done by the publication of a separate pamphlet ( $1 s .6 d$.) bearing the imprint of the Society and following the form of its Journal. The discussion was opened by Mr. C. N. Hinshelwood, whose subject was the energy of activation of chem. ical reactions. The magnitude and nature of activation energy, catalytic phenomena, and the contributions of quantum mechanics to the problem were among the matters considered. Mr. E. J. Bowen followed with a paper on photochemistry and chemical reactivity, referring to photosensitisation, the phenomenon of "predissociation" discovered by Henri, and the direct reaction of excited and normal molecules. Prof. A. J. Allmand's contribution dealt with the variation of quantum efficiency with wave-length in photochemical reactions; five different types of effect are distinguished, and their incidence in affecting the quantum yield was examined. Prof. E. K. Rideal discussed transition reactions, while Dr. F. G. Soper gave an account of researches on the effect of solvents on reaction velocity. Dr. $T$. Iredale communicated a short contribution dealing with the heat of activation of hydrogen iodide. In the spontaneous discussion which followed, Dr. R. G. W. Norrish, Mr. C. R. Bailey, Prof. Allmand, Mr. H. W. Thompson, and Mr. Hinshelwood took part. Their observations, together with the full text of the principal contributions, are to be found in the publication already mentioned.

\section{Preservation of the Fauna of the Empire}

IN a short address at the general meeting of the Society for the Preservation of the Fauna of the Empire, the chairman, Sir Peter Chalmers Mitchell, made a strong appeal for the consolidation of the position in regard to animal reserves within the Empire. At present the continued existence of faunal reserves depends upon the goodwill of individual governments or individual parliaments. The discovery of mineral deposits, the demand for timber, and other possible eventualities, may lead to particular reserves being thrown open to traffic or trade, with disastrous effects to the anirnal population, which cannot be herded into new areas at the will of man. What is needed for the permanent protection of those faunas, which are rapidly becoming relict faunas, is the raising of the status of their native territory in certain cases from temporary reserves to permanent national parks. The Society, which since its foundation has worked so strenuously on behalf of the Empire's threatened animals, has often appealed, with reasoned arguments founded upon the reports of its own observers, to the Colonial Office, but so far without success. The alteration would involve no extra expenditure; ultimately, indeed, the national parks by proper administration would bring in a certain amount of revenue; the surplus earned by the Game Department of Kenya, under strictly regulated conditions, was $£ 15,022$ in 1930 . At present their creation would cost nothing, and would mean permanent security for the animals and plants in the reserved regions.

WE strongly commend the campaign which the Society has launched for the spread of news relating to wild life. A short time ago we read in a northern newspaper an account of life in the forests of British Guiana; and the article was to be followed in the course of a few days by a lecture. $I t$ is excellent propaganda, the educational value of which must be appreciated by everyone interested in Nature and its preservation. The Society has in all 867 members; it deserves and ought to have many more. May we suggest that somewhere, say on the blank eover of the Journal, from the December number of which we have quoted, a note should appear of the conditions of membership and of the amount of the annual subscription.

\section{Frequency Range of Broadcast Receivers}

IN opening a discussion on the selectivity of broadcast receivers at the Institution of Electrical Engineers on Feb. 24, Prof. C. I. Fortescue said that as the apparatus tested becomes more and more sensitive, components of higher and higher frequencies are found in it. The female voice is known to have components having frequencies so high as 10,000, and footfalls, hand-clapping, and the operation of typewriters are observed to have components of frequencies approaching 16,000 . In broadeast transmitters provision is not usually made for such a wide range, and nearly every receiver has a much more limited range. A lower frequency limit of 50 and an uppor limit of 5000 are ustally considered to give good results. In the production of talking films, the audio-frequency output is, perhaps, subjected to the most careful scrutiny. In this case there is a noticeable tendency to try to get a full response up to a frequency of 10,000

The problem of getting uniformity of response over the whole audible range is more difficult. A highly trained observer detects, at particular frequencies, increases or diminutions in the loudness which the ordinary person does not notice. 'Musical' people are sometimes even the least critical of all in this

No. 3253 , VoL. 1293 
respect, owing to their peculiar power of imagining all the missing parts, just as in an ordinary telephone conversation the listener himself occasionally pro* vides as much as fifty per cent of the intelligibility. It was mentioned that there is a good deal of evidence to show that many receivers accept high-frequency energy over a far wider range of frequency than is necessary. The result is that they suffer from serious interference, as the waves of transmissions on neighbouring frequencies and the programmes they carry are also heard. It would obviously be better to limit the high-frequency range. The question of whether the average purchaser of a broadcast receiver can be entrusted to get the best results from a sharply tuned high-frequency circuit is one that can only be settled by statisties.

\section{Fisheries of the Thames Estuary}

IN a note in NATURE of May 11, 1927, attention was directed to the unpublished reports of Dr. James Murie on the Thames Estuary fisheries. Before his death in 1925, Dr. Murie had published the first part of his "Report on the Fisheries of the Thames Estuary ", containing Sections I to 3 and the greater part of Section 4. The second part, consisting of a large folio volume now in the Southend Public Library, was not published. Part of this is in galley proof, but the sixth section is in manuscript, and was written probably between 1895 and 1912. It was found in 1926 in an outhouse of Dr. Murie's cottage at Leigh, and consisted of a sodden mass of paper. The sheets were carefully separated, dried, and transscribed by the Borough Librarian, Mr. Pollitt, and a digest of this unpublished section is embodied in a long article by Mr. A. Laurence Wells, published in the Southend Standard (Jan. 7 and 14, 1931), entitled "Special Thames Estuary Fisheries". The matter is full of interest and covers a wide field. It consists mainly of detailed notes on the various fisheries in the Thames Estuary, especially those relating to the Leigh fishermen, and embraces the history of many of the older industries and the methods employed, both ancient and modern. These carefully collected data about each individual fishery are of historical value. Many of the methods are now obsolete, but most of the fisheries themselves are still flourishing.

Whitebaiting is a comparatively recent industry among the Leigh fishermen. Some two hundred year's ago it was practised up the river beyond Blackwall, but pollution of the water has driven the whitebait more to the Thames mouth, where the fishing is principally carried on. At first they fished only in spring, then in the original season from February to August; now they fish throughout the year. Shrimping, on the other hand, is an industry of long standing, begun. about a hundred years ago. Starfish dredging used to be profitable, now it is almost extinct. The fivefinger star is a great enemy of the oyster, and in dredging for them the fishermen not only helped the oyster but also utilised the starfish by selling them to the farmer for manure. Now, however, owing to chemical manure, the farmer no longer wants them. Other enemies which are much dreaded both by the whitebaiters and the shrimpers are the jelly-fishes and ctenophores, known by them as 'flat gall' and 'nut gall'. These come swarming from the sea during April and May, clogging the nets so that a continual and wearisome sorting is necessary. This manuscript is an important addition to the literature concerning the Thames Estuary fisheries, and all workers on the subject are indebted to those who have made it available to the public. Although containing about 22,000 words, it is obviously unfinished, for further sections were indicated consisting of notes on many other specialised forms of fishing.

\section{Geodesy in India}

The Geodetic Report of the Survey of India, vol. 6, deals with the very varied and extensive work done during the period Oct. 1929 Sept. 1930. A regular latitude variation programme has been started, supplementing the regular longitude observations, and in due course will throw light on the existence or otherwise of crustal drift. The irregularities in the longitude results remain unexpectedly large: to improve the time-keeping, a Shortt clock has been obtained. The form of the geoid in India and the gravity work have now brought irrefutable confirmation of Burrard's Hidden Range, which at first was inferred from rather scanty deflexion data; the Hidden Range is found to be flanked on both sides by troughs. Again, the levelling results obtained in Bengal during the last seventy years have been discussed. The closing errors of the various circuits are found to be surprisingly large, much greater than should occur in the class of levelling explained. It appears that they can be simply and naturally explained by supposing that real changes of level have occurred. Parts of the alluvial plains of northern Bengal and Bihar seem to have been rising at the rate of one foot in twenty years; tidal records indicate that Calcutta is not sinking, so that the country farther north is presumed to be rising. Further, tidal predictions for the Indian Ocean have been published in a new and cheap form of greatly increased scope, on lines similar to those of the Admiralty Tide Tables.

\section{British Museum (Natural History) Acquisitions}

Among the recent acquisitions by the Department of Zoology are two important gifts from the Rowland Ward trustees, namely, the skull and horns of a fine specimen of the giant sable antelope from Angola and a group of the little ant-eater from northern Brazil. A valuable collection of birds has been received from Mr. R. E. Moreau, secretary and librarian of the East African Agricultural Research Station at Amani, Tanganyika Territory. This collection, which was made by the aid of a grant from the Godman Exploration Fund, consists of some four hundred specimens belonging to about two hundred species, of which eight appear to be new to science. Acquisitions in the Department of Minerals include a large block of granite showing quartz-porphyry and a vein of aplite, from Penryn, Cornwall, presented by Mr. Ernest H. Davison; samples of platinum ore from Southern Rhodesia, presented by the director, Geological Survey of Southern Rhodesia, and specimens from 